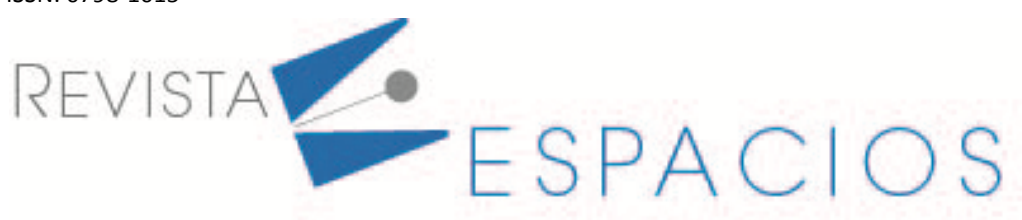

Vol. 41 (49) $2020 \cdot$ Art. 21

Recibido/Received: 09/10/2020 • Aprobado/Approved: 03/11/2020 • Publicado/Published: 23/12/2020

\title{
Technocratic governors: a new style in the political space of the Russian Federation ${ }^{1}$
}

\section{Gobernadores tecnocráticos: un nuevo estilo en el espacio político de la Federación Rusa}

\author{
EVTEKHOV, Roman A. ${ }^{2}$
}

\begin{abstract}
The paper deals with the problems of political style development in the Russian Federation governors' corps. There is few research on the issue of federal subjects heads' political style, which makes it necessary to consider it. The transformation of the democratic governing model in the 90 's into a vertical one resulted in the change of the political roles and the participation of governors. In this regard, the modern style of political leadership of Russian governors was developing under the influence of some basic elements of the political system. The article highlights the main characteristic elements under the influence of which the political style of governorship is formed, in particular, institutionalization, professionalization, the significant role of informal ties, the formal responsibility to the population (voters), the lack of opportunities in setting a political agenda, and others.

Key words: technocracy, political style, governors, russian federation, political space, federal subjects.
\end{abstract}

\section{Resumen:}

El documento trata los problemas del desarrollo del estilo político en el cuerpo de gobernadores de la Federación de Rusia. Existen pocas investigaciones sobre el tema del estilo político de los jefes de sujetos federales, lo que hace necesario considerarlo. La transformación del modelo de gobierno democrático en la década de los 90 en uno vertical resultó en el cambio de roles políticos y la participación de los gobernantes. En este sentido, el estilo moderno de liderazgo político de los gobernadores rusos se estaba desarrollando bajo la influencia de algunos elementos básicos del sistema político. El artículo destaca los principales elementos característicos bajo cuya influencia se configura el estilo político de gobernanza, en particular, la institucionalización, la profesionalización, el papel significativo de los vínculos informales, la responsabilidad formal con la población (votantes), la falta de oportunidades en la configuración. una agenda política, y otros.

Palabras clave: tecnocracia, estilo político, gobernadores, federación de rusia, espacio político, sujetos federales.

\section{Introduction}

Do not use initial indentation for any case. The alignment will be to the left and never justified since html does not correctly respect this instruction. The political space of hybrid regimes, which researchers often refer to as "managed democracies" or "democraduras", is largely "cleansed" by the authorities in order to eliminate competition. At the same time, hybrid regimes show some flexibility in contrast to authoritarian and totalitarian

\footnotetext{
${ }^{1}$ The research was carried out with the financial support of the Russian Fund of Fundamental Research (RFFR) and Expert Institute of Social Research (EISR) in the framework of the research project No. 20-011-32004 "Manager political style development in the regions of Russia: history and modernity".Funding: The reported study was funded by RFFR and EISR, project number № 20-011-32004 «Manager political style development in the regions of Russia: history and modernity».

${ }^{2}$ Candidate of Historical Science, Researcher at the Department of History and Theory of Politics, Lomonosov Moscow State University Moscow, Russian Federation. Email: lib-lab-scan@mail.ru
} 
regimes, which is the key to their longer existence. But throughout the entire period of its validity, such a regime is looking for ways and approaches to prolonge itself. One of these methods is a specific personnel policy, which forms a certain political style in management.

In the modern Russian Federation, the highest state power has not changed for more than twenty years. The vertical power system was practiced during the whole period, with the exception of the short term of $D$. A. Medvedev's presidential term . It cannot be said that the political style of the system was developed by the leader himself (V.V. Putin), because the development of a management style is a phenomenon influenced by many factors and rooted in political and historical traditions, in the system of power, in the relationship between society and the state, etc. However, the development of a modern style of political governance in the Russian Federation is a natural result of the verticalization development.

\section{Scientific problem}

Management style or political style is a manager's typical manner and a way of behavior. There are many different classifications based on various arguments. Each classification has a solid factual basis. Among many political styles that are distinguished in the modern Russian Federation, the rhetoric about the commitment of the young federal subject heads to the style of technocracy is of particular interest. This idea was brought up in numerous online and paper media, which started writing about the appearance of such style from 2017.

Technocracy is a broad concept that describes how scientists and technical specialists hold the main structures of power and implement specific applied economic tasks. The highest management positions in such a society are held by people not in accordance with their political views, but in accordance with their professional abilities and experience. If we understand technocracy in this sense, we must agree with the opinion that such a layer has not yet developed in Russia [Bezruchenko, 2014: 80]. However, if we consider the concept of technocracy in relation to the management, especially in large companies, then the focus shifts to preventing the broad masses of employees from developing and influencing any management decisions. Management in such companies is reduced not to the development of management strategies and not to the solution of management tasks and problems, but to control the activities of the personnel fulfilling the tasks set by the higher management. The definition of technocracy [Corrias, 2017: 490] as a regime of expert power in this case has nothing to do with reality. As we will see later, almost none of the new Russian governors are connected with the region and they do not have any experience which is connected with gubernatorial management, which allows some experts to call them "parachutists". In the Russian reality technocrats are rather a layer of managers with significant experience in bureaucratic work who are sent by the federal government to the regions to solve specific, applied tasks. Few of them can be characterized as researchers or technical specialists.

\subsection{The essence of technocracy and the reasons for its appearance in Russia}

The political style of the Russian Federation modern governors' corps is a fusion of two political systems: the Soviet nomenclature system and the West-oriented democracy that replaced it. Of course, one can argue whether the government in the 90's was a democracy in the western sense or not. However, the modern Putin's system of power in Russia is nothing more than a form of managed (limited) democracy. In accordance with this position, the political behavior style of the governors is being developed.

As for the discourse of the technocratic approach in Russian politics, it has actually replaced D. A. Medvedev's ideas of modernization and the concept of "effectiveness". Actually, the effectiveness is a concept of a managerial sphere and it evaluates economic indicators to a great extent. It also requires a certain amount of maneuvers and free activity. The technocratic approach, which is mostly associated with the gubernatorial level, is more about minimizing the influence on the political agenda. The governor in this system of power becomes 
only a driving element of the structure, which is not associated with the local system of relations and can be easily replaced. The technocracy style is quite convenient in a system of managed democracy, since from the very beginning it excludes the possibility for the governor to be an independent political actor.

E. Nabiullina is considered to be the classic technocrat in the highest system of power in Russia. She has some autonomy in making decisions related to the activities of the Central Bank, but she coordinates all significant political decisions that may have long-term consequences with the Government and the President. Without doubt, her work shows that this style has significant flaws. After all, the technocrat focuses on solving the specific tasks set to him/her by the government - in this case, on the reduction of inflation, without estimating the futility of such measure (the economist of a more liberated style would prefer to focus on economic growth, people's incomes, etc.) Here we can clearly see a significant difference between a technocrat official and a technocrat governor. The governor is not just an appointed official, but also a political figure whose main task, according to the federal authorities, is not actually managing the region from the point of view of social economic development, but doing the tasks and achieving political results required by the federal authorities. He makes sure that the region has the correct results of voting in elections and that there are no serious manifestations of political tension, ethnic conflicts, strikes, mass demonstrations, and so on. In the 18th century, such monitoring of political order in the region was referred to as "deanery", which literally meant external order and calm, which generally corresponds to the political appointment of governors in Putin's system of power. In fact, the governors' future depends even more on how well they manage to solve political problems than on how they will solve the problems of economic management of their regions.

What is the governors' corps today (2020)? Most governors today are of senior age and they often have the personal trust of the President but not of the region's people where their career is realized. In comparison with the 1990's, nowadays the governors' corps is quite strongly "rejuvenated", about a quarter of the governors being under 45 years old. The youngest of them is only 31 years old, which was unthinkable a few years ago. The young governors interest the society a lot. It is the young governors who are often referred to as the representatives of the "technocracy", which, in our opinion, does not correspond to the current understanding of this term. Technocrats in relation to the governorship of the modern Russian Federation can only be understood as young specialists, managers who are assigned a certain range of tasks without the right to influence the political course. Roughly speaking, they are entrusted with a wide range of powers (mainly to solve the problems of the region) with the actual immobility of the regime.

\section{Results}

The former link of governors changed quite actively before the presidential elections in 2018, which can be explained by the concern of the apparatus for the course and the results of the elections. Most often, these changes are associated with the strategic vision of the first Deputy head of the presidential administration, Sergei Kireenko. The media call the governors chosen after 2017 "young, innovative, and functional". It is very interesting that none of the new governors is either associated with the region or linked to it somehow. Even elected in Buryatia A. Tsydenov, an ethnic Buryat, is perceived as a "parachutist" who is not tied to the region.

What is this technocratic image of governorship like? First, this is a characteristic of an exceptionally young level of governors, whose faces are not associated with any negative things. Secondly, they have a very formal link to the region, most of the technocrats either had no significant work experience or they come from the region. Third, the new level of governors to some extent have the experience and skills of a modern manager. It is curious that none of the new gubernatorial staff in 2017-2020 were in any way connected with the local elites when they were appointed. Here you can see the influence of the groups from the center, which again corresponds to the old vertical principle. 
Another characteristic of the technocratic corps of governors in the Russian Federation is the complete lack of qualities of a charismatic leader. Despite having so-called "American behavior model", when governors communicate with voters directly, smile, shake hands, promise that "everything will be fine", none of the new governors demonstrates any skills of eloquence, "lively" behavior, etc. Even the voters perceive this behaviour as cold, and as a learned and a required element of their conduct. The pre-election situation in Buryatia since A. S. Tsydenov's appointment as acting President in February 2017 can serve as an example. Communicating with voters, Tsydenov generously made bold promises, which was initially perceived by voters with optimism. Such warm reception of his promises was due to the image of a person who can keep his promise, a person who understands and shares the problems of the region. However, it became obvious almost immediately that most of the promises could not be fulfilled. To some extent, the society even expresses sympathy for such governors, because they understand in advance that the governors are placed in very difficult conditions.

It is important to note that the young generation of Russian governors have chosen a rather unusual strategy: to call themselves a technocrat is like demonstrating to others that they are not engaged in elections, but in economic development, job creation and construction. However, experience shows that the heads of regional executive authorities are asked to ensure neither the quality of management nor the development of the economy, but they are responsible for the political agenda. It is interesting to note the governors behavior in the context of COVID-19 spread. The federal authorities have clearly shown interest in the political agenda, as indicated by their work on the restrictions and recommendations to abandon mass events in difficult conditions: the Victory parade (June 24), the vote for amendments to the Constitution (June 25 - July 1, 2020), the return of schoolchildren and students to educational institutions (September 1), etc. At the same time, all responsibility for carrying out preventive measures in the regions is entirely assigned to the governors. In this regard, the Russian media in August and September gave optimistic forecast on the coronavirus and, in fact, there was a statement on the victory over COVID-19 from the federal authorities, but the regional leaders were extremely cautious, giving moderate assessments of the situation. In fact, it works like this: the federal authorities are usually praised for their victories, including the declared victory over COVID-19, but the heads of subjects (governors) are responsible for solving problems related to it, including ensuring stable situation in the regions, solving economic problems resulting from it, and complete personal responsibility for sudden outbreaks of Covid19 and the spread of the epidemic. It is not for nothing that back in April 2020, at a meeting with the heads of the federal subjects, V. V. Putin quite clearly announced that if the number of Covid-19 cases sharply increases, it will be considered as a fault of regional authorities. After this event, some analysts expressed the opinion about high probability of suppressing the true statistics of morbidity and mortality. By the way, it coincided with a sharp stabilization of the statistics on those who fell ill and died from coronavirus and with the cessation of its growth.

The technocratic principle in the management system was considered successful by the federal authorities, since in the September 2020 elections most positions of new governors or acting governors were also occupied by technocrats. Again, technocrats are not economists, but rather managers who are sent by the federal center to solve a certain number of problems that are considered a priority for a particular region. For example, V. V. Uyba, the acting President of the Komi Republic, was appointed and then elected to address the complex epidemiological situation in the region, being an experienced official of the Ministry of Healthcare. To solve this problem, the following governors were also appointed: D. M. Mahonin, A.V. Tsybulsky, D. P. Butsaev, etc. The regions of Irkutsk and Khabarovsk were known for ambiguous appointments, both of which are associated with strong "anti-Moscow" (against the federal authorities) sentiments. Most elected heads of subjects were nominated by the party in power, although the logic of technocracy itself does not imply any rigid ideological guidelines, because the technocrat is primarily aimed at solving specific applied problems. Most elected governors had no contact with the regions prior to their appointments. At the same time, the new governors 
since 2017 rarely meet the qualification requirements, some of the governors have minimal or no management experience, almost none of them have worked in regional management and they come from different sectors.

\section{Conclusions}

In conclusion, we can say that the new link of governors in the Russian government system is in fact an adherent of technocratic governing principles. It means that the Governor does not hold any personal ideological beliefs, but recognizes the rhetoric of the federal center as fundamental. Based on this, the technocratic governor is often only formally a representative of the party in power, which is more likely to mark his affiliation, but not his beliefs. At the same time, the government is in no hurry to completely remove the governors from the party system, because this will significantly weaken the control over them. Then, the governor of a more or less calm region together with the local government aims at solving the main problems: 1 ) a political one (including holding elections with expected results) and 2) a socio-economic one.

It is impossible to call the modern Russian government, including the gubernatorial level, technocratic in the sense of the XXth century, because most of them are specialists in various fields of economics and management, but there are no reformers in this system of government who are able to bring their regions to a new level of development. The obvious reason for this is the established political system of the Russian Federation, where the heads of constituent entities appointed by the federal authorities are given specific goals and a very limited set of tools for solving them. The centralization of power and its total drain from the regions hampers prospects of growth. There is an assumption that the federal center itself understands this, so it prefers to appoint governors to the regions who will not fight the system, but those who will obediently work within a clearly defined framework. Despite a young generation of governors, they have very strictly outlined limits of their responsibilities.

A characteristic feature of the technocratic style of governors is the so-called parachutism - sending governors to regions with which they are not connected. They are not associated with the regions in any way and are guided by the federal authorities. In addition, technocratic governors have very little connection with the regions where they work, and very few of them have practical experience in managing regions. Most often, these are officials of various departments with significant experience in bureaucratic work.

\section{Acknowledgement}

The research was carried out with the financial support of the Russian Fund of Fundamental Research (RFFR) and Expert Institute of Social Research (EISR) in the framework of the research project No. 20-011-32004 "Manager political style development in the regions of Russia: history and modernity".Funding: The reported study was funded by RFFR and EISR, project number № 20-011-32004 «Manager political style development in the regions of Russia: history and modernity».

\section{References}

\section{Articles}

Corrias L. The Empty Place of European Power: Contested Democracy and the Technocratic Threat // European Law Journal. 2017. Vol. 23. Iss. 6. P. 482-494.

Esmark A. Maybe It Is Time to Rediscover Technocracy? An Old Framework for a New Analysis of Administrative Reforms in the Governance Era // Journal of Public Administration Research and Theory. 2017. Pp. 501516. 
Levitsky S., Way L. The Rise of competitive authoritarianism // Journal of Democracy. - 2002. - Vol. 13, N 2. - P. 51-65. - DOI: https://doi.org/10.1353/jod.2002.0026

Bezruchenko V. A. Socio-philosophical analysis of the technocratic class as an integrated elite of the future // Bulletin of Omsk University. 2014. № 3. Pp. 80-81.

Jargalsaikhan D. DEMOKRATURA 1 // http://jargaldefacto.com/article/demokratura-1

Levkina A. O. Connotations of technocracy in the discourse on forms of innovative development of society // Society and power. 2017. № 6. Pp. 13-20.

Farukshin M. Kh. Technocracy: hopes and risks // Sociological research. 2019. № 5. Pp. 76-86 DOI:10.31857/S0132162500049597

\section{Books}

Bucchi M. (2009) Beyond Technocracy. Science, Politics and Citizens. New York: Springer-Verlag.

Kokoshin A. A. (2009) Technocracy, technocrats and neotechnocrats. Moscow: LKI Publishing House.

Makeev, S. V. (2005) The phenomenon of technocracy: socio-philosophical analysis. - Moscow: Moscow State University.

Esta obra está bajo una Licencia Creative Commons Attribución-NoCommercial 4.0 International

\section{(cc) EY-NC}

